\title{
Effect of Variable Protein and Energy Diet on Purine Derivatives Excretion and Quantitative Microbial Protein Production in Crossbred and Indigenous Calves
}

\author{
Ajay Singh $^{1 *}$ and Bandla Srinivas ${ }^{2}$ \\ ${ }^{1}$ Animal Nutrition, College of Veterinary Sciences (Sri Venkateswara Veterinary University), \\ Proddatur - 516360, Andhra Pradesh, India \\ ${ }^{2}$ I/c Dairy Production Section, Southern Regional Station ICAR-NDRI, Bengaluru - 560030, \\ Karnataka, India \\ *Corresponding author
}

\section{A B S T R A C T}

Keywords

Nutrient intake,

Genotypes, Phenotypic

plasticity, Microbial

protein

Article Info

Accepted:

18 October 2018

Available Online:

10 November 2018
Study was conducted to evaluate the effect of enhanced level of nutrition on nutrient intake and microbial protein (MBP) production of two genotypes; Deoni and HF crossbred calves. Treatment groups of Deoni (DTG) and HF crossbred (XTG) were fed $30 \%$ more protein and energy as compared to their respective control groups (CGs). Dry matter intake (DMI) of DTG was reduced by $18 \%$ in comparison to DCG. Crude protein (CP) intake in DTG was $312 \mathrm{~g} / \mathrm{d}$ and was higher by $14 \%$ compared to DCG. Whereas, CP intake in XTG was $38 \%$ more compared to XCG. Gross energy (GE) intake by DTG was $8.13 \mathrm{Mcal} / \mathrm{d}$ compared to $9.70 \mathrm{Mcal} / \mathrm{d}$ of DCG. The MBP production in XCG, XTG, DCG and DTG was 239, 229, 143 and $142 \mathrm{~g} / \mathrm{d}$, respectively. Quantitative availability of MBP was constant and related to size of the calf. This indicated that the DMI in Deoni calves was regulated by the nutrient density of diet indicating towards the low level of phenotypic plasticity of digestive system in Deoni calves providing less scope for productive improvement by nutritional intervention compared to HF crossbred calves.

\section{Introduction}

Nutrition is the primary entity to be look after for better body growth. Faster growth entails more amounts of nutrients input through the diet. Often growth slumps immediately after weaning due to shift in nutrition from high density nutrient diet to roughage-based diet with supplements. And also, nutrition is all too often neglected between weaning and 9 months of age. Weaning to 9 months of age is a critical time in the life of a calf and is a time of higher nutrient requirements. As rumen capacity is limited during this period, a diet high in protein and energy content should be provided. In absence of adequate nutrition, the average daily weight gain (ADG) of calves would be less than genetic potential and fails to obtain required body weight as per the age. Insufficient growth rates result in an older age at first calving (Van Amburgh et al., 2008) which ultimately affects the overall productive life of the animal. Diet with CP content of 17 to $18 \%$ (DM basis) is recommended for calves 
less than $250 \mathrm{~kg}$ BW (Kertz et al., 1987). Brosh et al., (2000) have noted higher weight gain in male HF calves fed high protein diet $(14.6 \%)$ in comparison to feeding medium $(12.6 \%)$ or low $(10.6 \%) \mathrm{CP}$ diets. Whereas, Lohakare et al., (2006) found a diet with $12.6 \% \mathrm{CP}$ can provide adequate digestible protein at the intestine for the growth. Purine derivative (PD) excretion in the urine has proved to be a useful index of microbial protein flow to the small intestine of ruminants (Chen et al., 1990; Balcells et al., 1991). The efficiency of microbial nitrogen supply (EMNS), in terms of $\mathrm{g}$ microbial N/kg varies at different level of intake (Liu et al., 2000). Researchers have suggested that the urinary excretion of PD could be used as a predictor of the MBP supply in intact animals (Arndt et al., 2015; Wang et al., 2015).The purpose of this investigation was to study the effects of increased protein and energy level in the diet on intake and microbial protein production pattern.

\section{Materials and Methods}

\section{Location of study}

Experiments were conducted at Livestock Research Centre, Southern Regional Station, ICAR-NDRI, Bengaluru. The latitude $(\Phi)$, longitude $(\lambda)$ and elevation of the experimental place is $12.947014^{\circ} \mathrm{N}\left(12^{\circ} 56^{\prime}\right.$ 49.2504" N), 77.607679 (77 36' 27.6444" E) and $921 \mathrm{~m}$ from mean sea level, respectively. The climate here is tropical. The summers are much rainier than the winters in Bengaluru. This climate is considered to be Aw according to the Köppen-Geiger climate classification. The temperature here averages $23.6{ }^{\circ} \mathrm{C}$. In a year, the average rainfall is $831 \mathrm{~mm}$. The driest month is January, with $1 \mathrm{~mm}$ of rain. The greatest amount of precipitation occurs in September, with an average of $182 \mathrm{~mm}$. April is the warmest month of the year. The temperature in April averages $27.1{ }^{\circ} \mathrm{C}$. The lowest average temperatures in the year occur in December, when it is around $20.7^{\circ} \mathrm{C}$. There is a difference of $181 \mathrm{~mm}$ of precipitation between the driest and wettest months. The variation in temperatures throughout the year is $6.4{ }^{\circ} \mathrm{C}$ (https://en.climate-data.org/location/ 4562/). The experiment was conducted between September 2016 and February 2017.

\section{Experimental design and management of Animals}

The experimental design was a randomized complete block design with four treatments and five replications. Weaned female calves of Deoni and HF crosses at the age of 3 months were selected ten each for the study and randomly distributed into 4 equal groups; 1) Deoni Control Group (DCG), 2) Crossbred Control Group (XCG), 3) Deoni Treatment Group (DTG) and 4) Crossbred Treatment Group (XTG).The mean birth weights of Deoni and HF cross calves were 19.90 \pm 2.02 and $29.40 \pm 4.67 \mathrm{~kg}$ respectively. The body weights $(\mathrm{BW})$ at the start of experiment were $61.90 \pm 4.45$ and $64.70 \pm 6.18 \mathrm{~kg}$ for Deoni and Crossbred (CB) calves respectively. Calves were housed in a well-ventilated shed having arrangement for individual feeding, well maintained drainage channels and covered with laterite clay tiles on a $15 \mathrm{ft}$ wall with $45^{\circ}$ inclination on $6 \mathrm{ft}$ stone pillars. All the experimental animals were kept under confinement in individual stalls under tail to tail systemand were provided free access to water. Animals were dewormed with generic product 'Fenbendazole' (Panacur® Vet, M/s Intervet India Pvt. Ltd.) prior to starting of experiment.

\section{Feeding of animals}

Based on the NRC (2001) recommendation and earlier records of growth rate, nutrient requirement for the $\mathrm{CG}$ of Deoni and crossbred calves was calculated. TG of Deoni 
and crossbred weaned calves were provided $30 \%$ enhanced protein and energy over, respective CGs. Calves were fed mixed grasses consisted of Para grass (Brachiariamutica), Hybrid Napier (Pennisetumglaucum X P. purpureum), Maize (Zea mays) and Guinea grass (Megathyrsus maximus) as green roughage sources and CS pellet (M/s Karnataka Milk Federation [KMF], Bangalore). CG and TG of Deoni and Crossbred weaned calves were fed, respective diets for a period of 6 months. Weighed quantities of CS were fed once daily at $8 \mathrm{AM}$. Mixed green grasses were fed at 10:00 AM.The ingredient composition and nutritive values of diets are presented in Table 1.

\section{Feeding trial and sample collection}

CG and TG of Deoni and Crossbred weaned calves were fed, respective diets for a period of 6 months. Digestibility trial was conducted after a preliminary period of feeding for 5 months. Trial was consisted of $5 \mathrm{~d}$ collection period. Feeding schedule of the calves during the trial period was also maintained as described above. Diet offered as well as refused (orts) was weighed daily. Representative samples of of each feedstuff offered, and residues were collected every day for evaluating the DM and for further laboratory analysis. Faecal sampling was done every day at 9:00 AM. The total quantity of faeces voided by each animal during $24 \mathrm{~h}$ was recorded, thoroughly mixed with gloved hands and composite sample of 150 to $200 \mathrm{~g}$ faeces was taken separately for each animal in clean dry polythene bags for further sub-sampling. Sub-sample of 1/100 of total faeces was taken for DM estimation i.e., about 50 to $60 \mathrm{~g}$. Dried samples of feed offered, orts, and feces were pooled for $5 \mathrm{~d}$. Another sub-sample of 1/400 of total faeces was preserved with known quantities of $10 \% \mathrm{H}_{2} \mathrm{SO}_{4}(\mathrm{~V} / \mathrm{V})$ in pre-weighed glass bottles for nitrogen estimation.

\section{Urine collection}

Spot urine sample was collected 2-3 times a day for 3-4 d at different time. $20 \mathrm{ml}$ of sample was collected from each calf every time and were filtered using four layers of cheesecloth following the method described by Balcells et al., (1992) and mixed with equal quantity of dilute sulphuric acid $\left(2 \% \mathrm{H}_{2} \mathrm{SO}_{4}\right)$ to avoid volatilization of ammonia and stored at $-20^{\circ} \mathrm{C}$. Finally, one sample of each calf is pooled from all the samples of the same animal and were stored at $-20^{\circ} \mathrm{C}$ and preserved till further analysis.

\section{Chemical analysis}

Feed (offered and residue) and faecal samples collected during the digestibility trial were analysed for proximate principles and cell wall constituents (CWC) as per AOAC (2012). Proximate principles and CWC was determined as difference between total intake and faecal output.

\section{Microbial protein estimation}

Microbial nitrogen (MBN) production was estimated from the spot urine samples using purine derivatives (PD) and creatinine as markers in the urine (Chen et al., 1995). Urine samples were thawed, and $20 \mathrm{ml}$ aliquots were taken, centrifuged and filtered through a Millipore filter of $0.2 \mu \mathrm{m}$ pore size $(\mathrm{M} / \mathrm{s}$ Sigma Aldrich, Cat no. F-1387). One ml of the filtrate was taken and diluted 10-fold with HPLC grade water after adjusting the $\mathrm{pH}$ to 7.0 using $0.01 \mathrm{~N} \mathrm{NaOH}$ and $0.01 \mathrm{~N} \mathrm{H}_{2} \mathrm{SO}_{4} .20$ $\mu l$ of processed sample was injected into HPLC. Allantoin, creatinine and uric acid in the urine were estimated using HPLC method (Aswin and Srinivas, 2015). Standard solutions of allantoin (M/s Sigma Aldrich, Cat no. 93791), creatinine (M/s Sigma Aldrich, Cat no. C4255) and uric acid (M/s Sigma Aldrich, Cat no. U0081) each containing 
$50 \mu \mathrm{g} / \mathrm{ml}\left({ }^{\mathrm{w}} / \mathrm{v}\right)$ of respective standards was separately prepared in HPLC grade water. HPLC (M/s Waters India Pvt., Ltd.) was run in isocratic condition using $\mathrm{C}-18$ reversephase column (M/s Waters India Pvt., Ltd., and $4.5 \times 260 \mathrm{~mm}$ I.D., $5 \mu \mathrm{m})$ with $10 \mathrm{mM}$ potassium dihydrogen phosphate $(\mathrm{pH} 4.7)$ as mobile phase. Flow rate was fixed at 1 $\mathrm{ml} /$ minute and reading was taken at $220 \mathrm{~nm}$ wavelength (Model 2489 UV/visible detector, M/s Waters India Pvt., Ltd.,). Peaks were standardized for allantoin, uric acid and creatinine by injecting $20 \mu \mathrm{l}$ of respective standard.

Excretion of total PD was calculated as below (Chen et al., 1995):

PDC index: It was calculated as the ratio of the concentrations of $\mathrm{PD}(\mathrm{mM} / \mathrm{L})$ to creatinine $(\mathrm{mM} / \mathrm{L})$ times the metabolic body weight (MBW)

$\mathrm{PDC}$ Index $=[(\mathrm{PD} \mathrm{mM} / \mathrm{L}) / \quad($ Creatinine $\mathrm{mM} / \mathrm{L})] * \mathrm{MBW}$

The following equation was used to determine the quantitative relationship between absorption of purines and excretion of PD (Y $\mathrm{mM} / \mathrm{d}$ ) in urine.

$\left.\mathrm{Y}=83 \mathrm{X}+0.296 \mathrm{~kg} \mathrm{~W}^{0.75}\right)$.

Where $\mathrm{W}^{0.75}$ represents the MBW $(\mathrm{kg})$ of the experimental calves. The slope of 0.83 in equation represented the recovery of absorbed purines as PD in urine and X was PDC index.

In crossbred cattle, the endogenous contribution was taken as a constant at $0.296 \mathrm{~W}^{0.75}$ per day (Singh et al., 2007; Pimpa et al., 2001; Chen and Orskov, 2003). Thus, the daily purine absorption was backcalculated as

$\mathrm{X}=\left(\mathrm{Y}-0.296 \times \mathrm{W}^{0.75}\right) \div 0.83$.
Intestinal flow of MBN was calculated from the excretion of PD as

$(\mathrm{X} \times 70) /(0.83 \times 0.116 \times 1000)$.

Where, the digestibility of microbial PD was $0.83, \mathrm{~N}$ concentration in purine was $70 \%$ and, 0.116 was the ratio between $\mathrm{N}$ in PD to total $\mathrm{N}$ in mixed rumen microbes.

Efficiency of MBN production was expressed as $\mathrm{g} \mathrm{N} \mathrm{kg}^{-1}$ of $\mathrm{OM}$ digested in the rumen (DOMR) by multiplying digestible $\mathrm{OM}$ by 0.65 .

\section{Statistical analysis}

Statistical analysis of data was performed using statistical package for social science (SPSS, ver.20.0 M/s IBM India Pvt. Ltd.). The data were analysed in a completely randomized design and significant variation between means was denoted by different superscripts. Pairwise comparison between group means was tested by Duncan multiple range test (DMRT). Significant difference between groups was expressed at probability (P) levels ranging from $<0.10$ to 0.01 and $\mathrm{p}$ value of $<0.10$ was demarcated using '•’ where as ' $*$ ' and ' $* *$ ' were used to denote $\mathrm{P}$ value of $<0.05$ and 0.01 , respectively and validated against null hypothesis $\left(\mathrm{H}_{0}\right)$.

\section{Results and Discussion}

\section{Chemical composition of basal diet and supplement}

The chemical composition analysis of the experimental feeds items constituting treatment diets is presented in Table 1. DM and $\mathrm{CP}$ content of green grass which was mixture of non-legume grasses was $19.72 \%$ and $5.10 \%$, respectively. The average $\mathrm{CP}$ content of the CS was $16 \%$. Density of CP, NFC and energy in GNJ supplement was 63\%, 
$74 \%$ and $10 \%$ higher than CS. The combination of GNC and Jaggery were supplemented to enhance intake of protein and energy by the calves.

\section{Feed and nutrient intake}

Nutrient intake from the total diet in different groups is given in Table 2. DMI from total diet was significantly less in DTG $(\mathrm{P} \leq 0.01)$ compared to DCG, XCG and XTG where later groups were statistically $(\mathrm{P}=0.08)$ comparable. Similarly, OM and TCHO was also significantly less in DTG $(\mathrm{P} \leq 0.01)$ but, comparable between the crossbred groups. $\mathrm{CP}$ intake was significantly low in DCG $(\mathrm{P} \leq$ $0.01)$. Total $\mathrm{OM}(\mathrm{P} \leq 0.01)$, EE $(\mathrm{P} \leq 0.01)$ and TA $(\mathrm{P} \leq 0.01)$ intake in XTG was higher than XCG. GE intake was significantly different among all the groups with DTG having the lowest value of $8.13 \mathrm{MCal} / \mathrm{d}$ whereas, XTG the intake was found highest $(13.73 \mathrm{MCal} / \mathrm{d})$ (Fig. 1)

\section{Microbial Protein Production}

Excretion of PD in urine and their index, MBP production with efficiency in different groups is presented in Table 3. Urinary allantoin excretion was significantly $(\mathrm{P} \leq 0.01)$ higher in TGs compared to respective CGs. Total PD was significantly low $(\mathrm{P} \leq 0.01)$ in $\mathrm{DCG}$ whereas it was comparable in XCG, XTG and DTG $(P=0.051)$. Similar was the case found regarding daily PD excretion with significant $(\mathrm{P} \leq 0.01)$ high value for HF crossbred calves. The MBP production in XCG, XTG, DCG and DTG was 239, 229, 143 and $142 \mathrm{~g} / \mathrm{d}$, respectively. Daily MBP production was significantly $(\mathrm{P} \leq 0.01)$ high in HF crossbred calves compared to Deoni animals. MBP production observed in XCG and XTG were 239 and $229 \mathrm{~g} / \mathrm{d}$ and comparable to adult crossbred cows. The efficiency of MBP production in relation to DOMI and ME intake was found insignificant $(P=0.15)$ among the groups (Fig. 2).
Chemical composition of basal diet and supplement

$\mathrm{DM}$ and $\mathrm{CP}$ content showed that the green grass fed was matured and leafy with moderately tender stems. CP content of leftover green fodder was lesser than offered whereas NDF content was higher thus, indicated the selective intake of animals by taking more tender leafy parts and shoots but leaving behind the comparatively hard and fibrous parts like thickened stems with nodes and internodes (Antongiovanni and Sargentini, 1991). The CP content of the concentrate was16\% which is considered average as according to Paulson (2009) the best CP\% for dairy animals is 11 to $12 \%, 13$ to $14 \%$ and 16 to $17 \%$, respectively in low, medium and high protein CS based on health and environment.

Excess protein in the ration may have detrimental effect on kidney and body extremities e.g., hooves, tail etc.

\section{Feed and nutrient intake}

DMI of DTG was reduced by $18 \%$ in comparison to DCG. In-spite of less DMI, CP intake in DTG was higher by $14 \%$ compared to DCG because of higher protein in GNJ (26\%) than pelleted CS (16\%). In case of Deoni calves, OM, TA and TCHO intake were less in DTG and more in DCG while contrary was true for their EE intake. Although GNJ was rich in $\mathrm{CP}$ and GE (4 Mcal/kg), GE intake by Deoni calves of TG ( 8.13 vs. $9.70 \mathrm{Mcal} / \mathrm{d})$ was $20 \%$ lesser $(\mathrm{P} \leq 0.01)$ than CG. This indicated that the DMI in Deoni calves was regulated by the satiety of $\mathrm{CP}$ intake. Diet composition has been suggested to have a large impact on satiety and satiation. It is generally believed that the major macronutrients differ in their effects, with protein having a greater effect than carbohydrate, which has a greater effect than fat (Hall et al., 2012). Singh and Srinivas 
(2016) observed 50\% lesser DMI with CS having $88 \%$ soymeal compared to CS having $42 \%$ soymeal as protein source thus, high protein supplements have been reported to limit DMI. Deoni calves in TG were restricted their intake with $14 \%$ higher protein intake but, GE intake was $16 \%$ lesser. In contrary, DMI of HF crossbred calves in TGs were not traded off even after consuming 38\% higher protein and 10\% GE. This showed limitation in phenotypic plasticity of digestive system to food intake in Deoni calves in comparison to HF crossbred calves. Phenotypic plasticity of digestive system has been explained as compensating low quality diet with higher intake to fulfil nutrients requirement to the animals or not limiting the total intake even when the density of nutrients is higher. In case of Deoni calves, metabolic finity is reached either in terms of quantity or quality of the diet thus, indicated less scope to improve any productive performance of these calves.

Table.1 Chemical composition of dietary ingredients

\begin{tabular}{|l|l|l|l|}
\hline Parameter & $\begin{array}{l}\text { Green fodder } \\
\text { Offered }\end{array}$ & $\begin{array}{l}\text { Concentrate } \\
\text { supplement }\end{array}$ & $\begin{array}{l}50 \% \text { GNC + } \\
\text { 50\% Jaggary }\end{array}$ \\
\hline Moisture (\%) & $80.28 \pm 0.37$ & $11.25 \pm 0.23$ & $7.05 \pm 0.42$ \\
\hline Dry Matter (\%) & $19.72 \pm 0.37$ & $88.75 \pm 0.23$ & $92.95 \pm 0.42$ \\
\hline Organic Matter (\%) & $89.61 \pm 0.58$ & $87.79 \pm 0.45$ & $93.61 \pm 0.68$ \\
\hline Crude Protein (\%) & $5.10 \pm 0.13$ & $15.59 \pm 0.58$ & $26.12 \pm 0.23$ \\
\hline Ether Extract (\%) & $1.75 \pm 0.05$ & $2.86 \pm 0.36$ & $5.35 \pm 0.06$ \\
\hline Total Ash (\%) & $10.39 \pm 0.58$ & $12.21 \pm 0.45$ & $6.39 \pm 0.68$ \\
\hline Acid Insoluble Ash (\%) & $3.09 \pm 0.11$ & $2.43 \pm 0.25$ & $0.90 \pm 0.04$ \\
\hline Total Carbohydrates (\%) & $82.76 \pm 0.56$ & $69.34 \pm 0.66$ & $62.15 \pm 0.48$ \\
\hline Cell Content (\%) & $34.27 \pm 0.72$ & $57.07 \pm 0.19$ & $84.59 \pm 0.21$ \\
\hline Neutral Detergent Fiber (\%) & $65.73 \pm 0.72$ & $42.46 \pm 0.27$ & $14.95 \pm 0.39$ \\
\hline Acid Detergent Fiber (\%) & $41.19 \pm 0.99$ & $11.03 \pm 0.40$ & $11.41 \pm 0.21$ \\
\hline Hemicelluloses (\%) & $24.53 \pm 1.08$ & $31.43 \pm 0.29$ & $3.54 \pm 0.48$ \\
\hline Celluloses (\%) & $33.70 \pm 0.72$ & $7.80 \pm 0.25$ & $8.04 \pm 0.07$ \\
\hline Acid Detergent Lignin (\%) & $4.99 \pm 0.23$ & $3.61 \pm 0.19$ & $2.83 \pm 0.09$ \\
\hline Non-Fibrous Carbohydrates (\%) & $17.03 \pm 0.32$ & $26.88 \pm 0.61$ & $47.21 \pm 0.47$ \\
\hline Gross Energy (Kcal/kg DM) & $3672 \pm 24$ & $3655 \pm 23$ & $4022 \pm 27$ \\
\hline
\end{tabular}

Table.2 Nutrient intake $(\mathrm{kg} / \mathrm{d})$ from total diet in different groups

\begin{tabular}{|l|c|c|c|c|c|c|}
\hline Parameter & XCG & XTG & DCG & DTG & SEM & P Value \\
\hline \multicolumn{7}{|c|}{ Nutrient Intake $\mathbf{( k g / d )}$} \\
\hline DM & $3.41^{\mathrm{c}}$ & $3.65^{\mathrm{c}}$ & $2.63^{\mathrm{b}}$ & $2.14^{\mathrm{a}}$ & 0.09 & 0.01 \\
\hline OM & $3.04^{\mathrm{c}}$ & $3.22^{\mathrm{c}}$ & $2.36^{\mathrm{b}}$ & $1.90^{\mathrm{a}}$ & 0.08 & 0.01 \\
\hline CP $(\mathrm{g} / \mathrm{d})$ & $3.79^{\mathrm{c}}$ & $5.22^{\mathrm{d}}$ & $2.75^{\mathrm{a}}$ & $3.12^{\mathrm{b}}$ & 0.07 & 0.01 \\
\hline EE & $0.073^{\mathrm{b}}$ & $0.139^{\mathrm{d}}$ & $0.055^{\mathrm{a}}$ & $0.083^{\mathrm{c}}$ & 0.01 & 0.01 \\
\hline TA & $0.362^{\mathrm{c}}$ & $0.436^{\mathrm{d}}$ & $0.277^{\mathrm{b}}$ & $0.241^{\mathrm{a}}$ & 0.01 & 0.01 \\
\hline TCHO & $2.59^{\mathrm{c}}$ & $2.60^{\mathrm{c}}$ & $2.03^{\mathrm{b}}$ & $1.53^{\mathrm{a}}$ & 0.07 & 0.01 \\
\hline GE $(\mathbf{M c a l})$ & $12.55^{\mathrm{c}}$ & $13.73^{\mathrm{d}}$ & $9.70^{\mathrm{b}}$ & $8.13^{\mathrm{a}}$ & 0.34 & 0.01 \\
\hline
\end{tabular}


Table.3 Purine derivatives excretion and Microbial Nitrogen production in different groups

\begin{tabular}{|l|l|l|l|l|l|l|}
\hline Parameter & XCG & XTG & DCG & DTG & SEM & P Value \\
\hline Allantoin (mM/L) & $13.51^{\mathrm{b}}$ & $18.45^{\mathrm{c}}$ & $8.42^{\mathrm{a}}$ & $17.70^{\mathrm{bc}}$ & 1.42 & 0.01 \\
\hline Uric acid (mM/L) & 4.22 & 5.44 & 2.44 & 3.67 & 0.97 & 0.23 \\
\hline Creatinine (mM/L) & $2.00^{\mathrm{ab}}$ & $2.87^{\mathrm{b}}$ & $1.63^{\mathrm{a}}$ & $3.05^{\mathrm{b}}$ & 0.35 & 0.04 \\
\hline Total PD (mM/L) & $17.74^{\mathrm{b}}$ & $23.89^{\mathrm{b}}$ & $10.86^{\mathrm{a}}$ & $21.37^{\mathrm{b}}$ & 1.92 & 0.01 \\
\hline PD index & $296.29^{\mathrm{b}}$ & $284.27^{\mathrm{ab}}$ & $213.59^{\mathrm{a}}$ & $210.91^{\mathrm{a}}$ & 25.13 & 0.06 \\
\hline PD excretion (mM/d) & $284.44^{\mathrm{b}}$ & $272.90^{\mathrm{b}}$ & $171.94^{\mathrm{a}}$ & $169.79^{\mathrm{a}}$ & 23.38 & 0.01 \\
\hline Duodenal flow of MBN (g/d) & $239.15^{\mathrm{b}}$ & $229.34^{\mathrm{b}}$ & $143.09^{\mathrm{a}}$ & $141.56^{\mathrm{a}}$ & 20.00 & 0.01 \\
\hline Efficiency of prod. (g N/kg of DOMI) & 131.31 & 104.94 & 102.84 & 108.05 & 10.35 & 0.24 \\
\hline Efficiency of prod. (g N/Mcal of ME) & 35.60 & 26.78 & 28.37 & 27.97 & 2.75 & 0.15 \\
\hline
\end{tabular}

Fig.1 Nutrient intake $(\mathrm{kg} / \mathrm{d})$ of nutrients in different groups

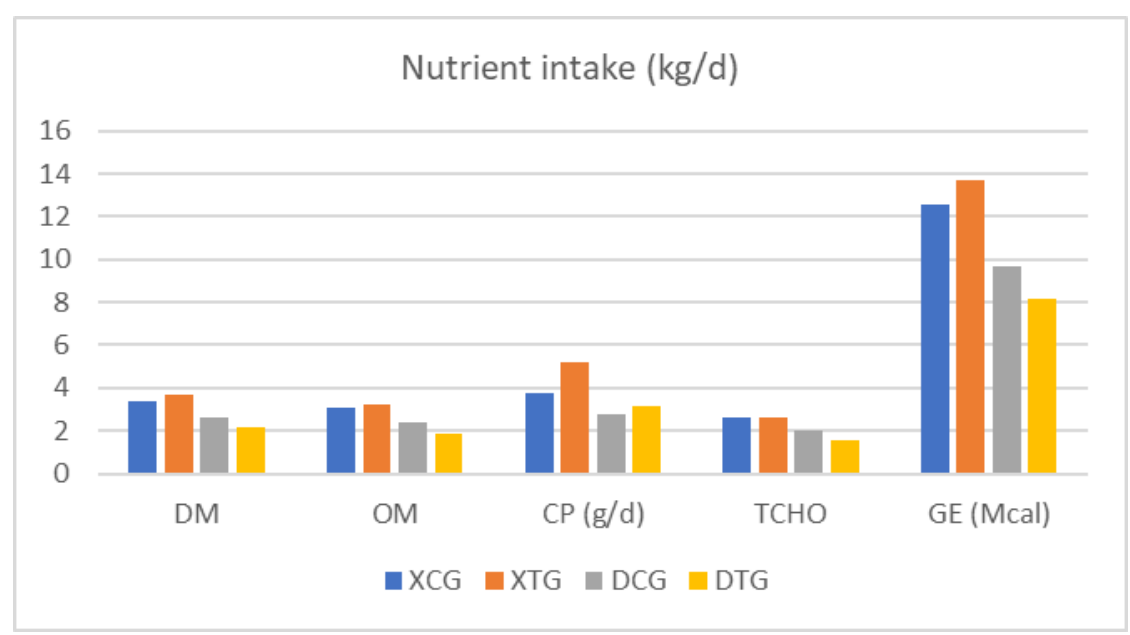

Fig.2 MBP production in different groups

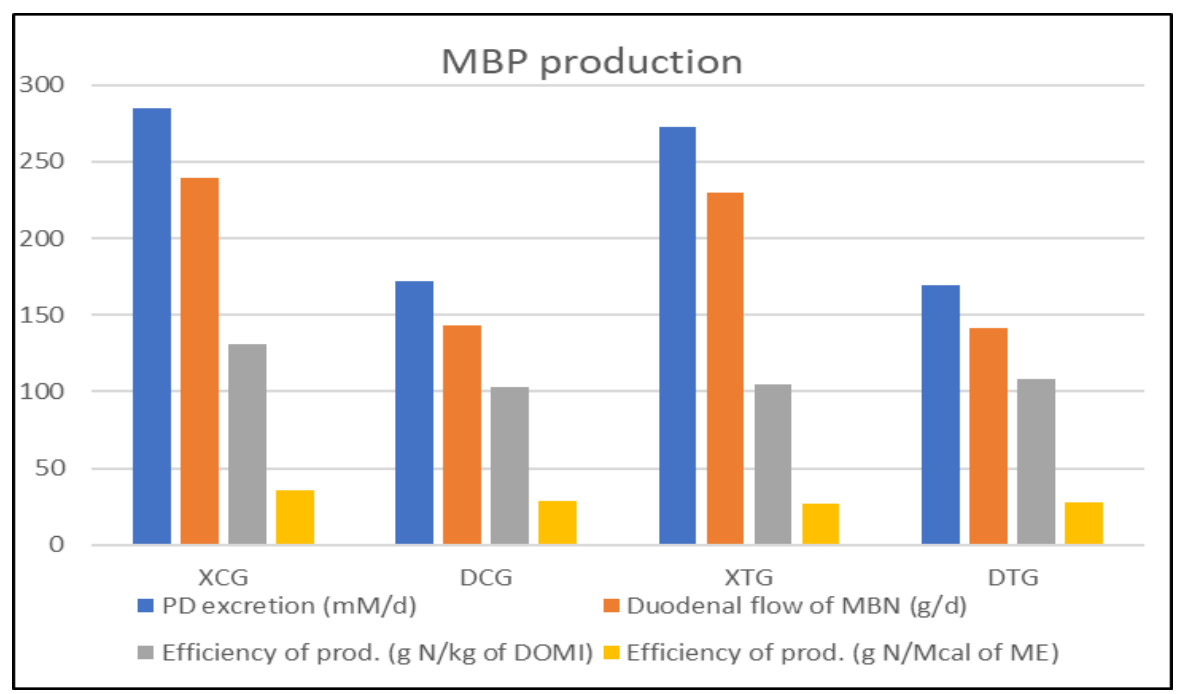


It is also a classic example for less plasticity of digestive system of Deoni calves where high protein intakes are limited by the aminopeptide $\mathrm{N}$ in digestive system (Dewitt et al., 1998).

\section{Microbial protein production}

Allantoin excretion in DTG was about 2 times higher than DCG. It was only $36 \%$ higher in XTG than XCG. This indicated higher metabolism of microbial PD at small intestine. Significantly low $(\mathrm{P}=0.04)$ creatinine concentration in DCG indicated the direct relationship with body weight and less metabolically active tissue (Oser, 1965). Srinivas and Singh (2011) reported excretion of 3.0 to $3.4 \mathrm{mM} / \mathrm{L}$ creatinine. Significant (P $=0.06$ ) breed difference was observed for the PDC index where HF crossbred calves were having higher PDC index. This indicated more MBP hydrolysed at small intestine in comparison to metabolically active tissue in the crossbred calves or vice-versa with Deoni calves. Urinary PD and duodenal flow of purine bases differs among species (Chen et $a l ., 1990)$ and within cattle species (Liang et al., 1994). MBP production in ruminants is influenced by various biological, physical and chemical factors pertaining to animal, feed and environment in rumen (Srinivas and Krishnamoorthy, 2013). Diet composition is important in MBP yield. MBP yield on grainbased diets were higher (Singh and Srinivas, 2016) than oilseed meals (Mohanavel and Srinivas, 2016). Grains which contain more starch is a principle component of NFC and its availability influences the rumen MBP production. Quantitative availability of MBP was constant and related to size of the cow in general and, rumen in particular. MBP production in crossbred cows was reported as low as $80 \mathrm{~g} / \mathrm{d}$ to $270 \mathrm{~g} / \mathrm{d}$ on straw diet without or with CS, respectively (Srinivas and Gupta, 1997). MBP production efficiency was $100 \mathrm{~g} / \mathrm{kg}$ DOMI which was higher than the optimum suggested $30 \mathrm{~g} / \mathrm{kg} \quad$ DOMR (digestible OM in rumen) where DOMR was $65 \%$ of digestible OM (DOM) intake (ARC, 1980). Optimum MBP production for $\mathrm{kg}$ DOM intake would be about $50 \mathrm{~g}$. In the present study, it was 2 folds more while Singh and Srinivas (2016) reported 50\% efficiency on grain-based diet in Deoni cows compared to present study. Mohanavel and Srinivas (2016) reported 30 to $39 \%$ on different types of oilseed-based CS as against the present study. By and large, the MBP production efficiency observed in the post-weaned calves was high irrespective of HF crossbred or pure Deoni breed that can be attributed to diet.

Total diet intake or digestible nutrients intake in weaned Deoni calves in comparison to $\mathrm{HF}$ crossbred calves was hindered due to limited phenotypic plasticity of digestive system. Thus, Deoni calf response to enhanced protein and energy would be limited by its capacity to dry matter intake and protein intake.

\section{Acknowledgements}

The authors extend their appreciation to National Dairy Research Institute (NDRI) for funding this work and for their support.

\section{Compliance with ethical standards}

The study was approved by the committee of ethics in Animal Experimentation.

\section{Conflict of interest}

The authors declare that they have no conflict of interests

\section{References}

Antongiovanni, M. and Sargentini, C. 1991. Variability in chemical composition of straws. Options Mediterraneennes Serie Seminaires. 16: 49-53. 
AOAC, 2012) Official Methods of Analysis. Association of Official Analytical Chemist. $19^{\text {th }}$ Edn. Washington, DC.

ARC 1980. The nutrients requirements of ruminant livestock. 4th Edition, $\mathrm{CAB}$ International, Wallingford.

Arndt, C., Powell, J. M., Aguerre, M. J., Crump, P. M. and Wattiaux, M. A. 2015. Feed Conversion Efficiency in Dairy Cows: Repeatability, Variation in Digestion and Metabolism of Energy and Nitrogen, and Ruminal Methanogens, Journal of Dairy Science. 98(6): 3938-3950.

Balcells, J., Guada, J. A., Castrillo, C. and Gasa, J. 1991. Urinary excretion of allantoin and allantoin precursors by sheep after different rates of purine infusion into the duodenum. J. Agric. Sci., Camb. 116: 309.

Balcells, J., Guada, J., Peiró, J., and Parker, D., 1992. Simultaneous determination of allantoin and oxypurines in biological fluids by high-performance liquid chromatography, Journal of Chromatography B: Biomedical Sciences and Applications, 575, 153157.

Brosh, A., Aharoni, Y., Levy, D. and Holzer, Z. 2000. Effect of dietary protein concentration and source on the growth rate and on body composition of Holstein-Friesian male calves. Anim. Sci. 70: 527-536.

Chen, X. B. and Orskov, E. R. 2003. Research on urinary excretion of purine derivatives in ruminants: past, present and future. In: Development, standardization and validation of nuclear based technologies for estimating microbial protein supply in ruminant livestock for improving productivity. IAEA 2003, Vienna. Pp. $1-34$.

Chen, X. B., De, F. D., Hovell, B., Orskov, E. R. and Brown, D. S. 1990. Excretion of purine derivatives by ruminants: Effects of exogenous nucleic acid supply on purine derivative excretion by sheep. British Journal of Nutrition 63: 131.

Chen, X. B., Mejia, A. T., Kyle, D. J. and Orskov, E. R. 1995. Evaluation of the use of the purine derivative: creatinine ratio in spot urine and plasma samples as an index of microbial protein supply in ruminants: studies in sheep. J. Agric. Sci., Camb. 125: 137-143.

Dewitt, T. J., Sih, A. and Wilson, D. S. 1998. Costs and limits of phenotypic plasticity. Trends in Ecology and Evolution. 13: 77-81.

Hall, Kevin D., Heymsfield, Steven B., Kemnitz, Joseph W., Klein, Samuel., Scholler, Dale A. and Speakman John R. 2012. Energy balance and its components: implications for body weight regulation. American Journal of Clinical Nutrition 95: 989-994.

Kertz, A. F., Prewitt, L. R. and Ballam, J. M. 1987. Increased weight gain and effects on growth parameters of Holstein heifer calves from 3 to 12 months of age. Journal of Dairy Science 70: 16121622.

Liang, J.B., Matsumoto, M., Young, B.A. 1994. Purine derivative excretion and ruminal microbial yield in Malasyan cattle and swamp buffalo. Animal Feed Science and Technology 47: 189-199.

Liu, Z. J. and McMeniman, N. P. 2000. Microbial Protein Production Estimated by Urinary PD Excretion and the Ratio of PD: Creatinine in Spot Urine Samples for Sheep Fed Lucerne Chaff at Different Levels of Intake. Asian Australasian Journal of Animal Sciences. 13: 31-33.

Lohakare, J. D., Pattanaik, A. K. and Khan, S. A. 2006. Effect of dietary protein levels on the performance, nutrient balances, metabolic profile and thyroid hormones 
of crossbred calves. Asian-Aust. $J$. Anim. Sci. 19: 1588-1596.

Mohanavel, S. and B. Srinivas 2016. Rumen microbial and milk protein production on different source of oilseed meals in mixed diet of Deoni cows. Indian Journal of Animal Science 86 (12): 8589.

National Research Council (NRC). 2001. Nutrient Requirements of Dairy Cattle. 7th rev. ed. Natl. Acad. Sci., Washington, DC.

Oser, B. L., 1965, Hawk's physiological chemistry. 14th ed. McGraw-Hill, New York, NY.

Paulson, J. 2009. Feeding dairy animals in $21^{\text {st }}$ century. Dairy Star. 16 October 2009.

http://www.extension.umn.edu/agricultu re/dairy/farm-life/ feeding-dairyanimals-in-the-21st-century. (DoA: 12/02/2017).

Pimpa, O., Liang, J. B., Jelan, Z. A. and Abdulla, N. 2001. Urinary excretion of duodenal purine derivatives in KedahKelantan cattle. Animal Feed Science and Technology. 92: 203-214.

Singh, A. P. and Srinivas, B.2016. Source of carbohydrates from different grains on rumen microbial protein and milk production in native dairy cows. Animal Feed Science and Technology 16(2): 297-306.

Singh, M., Sharma, K., Dutta, N., Singh, P., Verma, A. K. and Mehra, U. R. 2007.
Estimation of rumen microbial protein supply using urinary purine derivatives excretion in crossbred calves fed at different levels of feed intake. Asian Australasian Journal of Animal Sciences. 20(10): 1567.

Srinivas, B. and Gupta, B. N. 1997, Rumen fermentation, bacterial and total volatile fatty acid (TVFA) production rates in cattle fed on urea-molasses-mineral block licks supplement. Animal Feed Science Technology 65:275-286.

Srinivas, B. and Krishnamoorthy, U. 2013. Panoply of microbial protein production in ruminants - A Review. Indian Journal of Animal Science 83: 331-346.

Srinivas, B., Swain, N., and Singh, N. P. 2011. Quantification of nutritional sustenance and microbial protein production of sheep during different physiological stages in semi-arid regions. Indian Journal of Animal Sciences (India).

Van Amburgh, M. 2008. Early life management and long-term productivity of dairy calves. Proceedings of Southwest Dairy Management Conference. http://animal.cals.arizona. edu/swnmc/ 2008. (05-11-2016).

Wang, C. 2015. A Modified Machine Learning Method Used in Protein Prediction in Bioinformatics, International Journal Bioautomation. 19(1): 25-36.

\section{How to cite this article:}

Ajay Singh and Bandla Srinivas. 2018. Effect of Variable Protein and Energy Diet on Purine Derivatives Excretion and Quantitative Microbial Protein Production in Crossbred and Indigenous Calves. Int.J.Curr.Microbiol.App.Sci. 7(11): 2257-2266. doi: https://doi.org/10.20546/ijcmas.2018.711.253 